\title{
Building a values-based community of practice in Nursing Sciences during the Covid-19 pandemic
}

\author{
Debbie Holley \\ Bournemouth University, UK \\ Anne Quinney \\ Bournemouth University, UK \\ John Moran \\ Bournemouth University, UK
}

Keywords: Covid-19; values-based; assessment and feedback; confidence-building; blended learning.

\section{The challenge}

Delivering a rigorous Nursing and Midwifery Council (NMC) accredited academic and professional curriculum is complex; the government call for final year student nurses to fast-track their degree completion and enter clinical practice six months early as a response to the pandemic added a further challenging dimension. Distinctive features of teaching and learning in this department of Nursing Science are a curriculum built on the theory of humanisation (Todres, Galvin and Holloway, 2009) and values- based teaching and learning (Shulman, 2005; Crookes, Else and Lewis, 2020), informed by Wenger's (1999) communities of practice. This underpinning philosophy informed the support mechanisms introduced to support this complex scenario of online study and rapid pandemic-related deployment into clinical practice.

As traditional nurse education has involved high levels of face-to-face content both on campus and in clinical settings (Horsfall, Cleary and Hunt, 2012), few staff had experience or expertise in delivering online learning. However there was an in-house theoretical base to draw upon in developing theories of blended learning (Hutchings, Quinney and Galvin, 2014; Hutchings and Quinney, 2015). A rapid transition was needed to not simply move content online for our cohort of unexpectedly distanced learners, but to design interactive 
and engaging materials. Coupled with this, assessment practices were required to change to be in line with online teaching and learning. We drew upon the body of knowledge offered by learning development in this 'tilt to online' (Quinney et al., 2017; Nordmann et al., 2020), and this developed confidence in staff unfamiliar with this mode of delivery.

\section{The response}

The work of Biggs (1999) on constructive alignment, and Conole and Wills (2013) on learning design informed the range of different interventions we provided in order to support staff as learners. We report here on two initiatives which supported staff in making adjustments to teaching and learning strategies. The Corona Virus Teachinar set up in the university's Virtual Learning Environment, Brightspace, was delivered as a radio station 'chat show' on a daily basis, building the academic community. The second initiative supported efforts to make assessment and feedback changes more accessible to staff, delivered through a renewed focus on creating resources for our nationally acclaimed 'Assessment \& Feedback Toolkit'. By sharing opportunities for redesign through formal and informal channels, staff awareness of the options was built. Our learning designs needed to offer scaled-up and sustainable interventions and feature a supportive and inclusive approach which recognised the rapid learning required of academic staff in this unfamiliar teaching and learning context.

The Teachinar hosted live discussions, shared good pedagogic design, demonstrated how to use online learning tools, provided demonstrations in situ, and provided a 'safe space' for staff to try new approaches and build confidence. Adding all staff to the unit enabled easy access through everyone's Brightspace 'landing pages', ensuring prominence and accessibility. The familiar design and layout removed the need for staff to become competent in using another platform, replicating the familiar layout and content of a unit of study, which modelled the student experience. A popular feature was an informal daily chat hosted by the Faculty Learning Technologist and the academic project lead. This drew on Laurillard's 2002 work on conversational frameworks in order to listen to, reassure, and inspire staff, whilst modelling and reinforcing new practices. 
Our technology/pedagogic response was underpinned by Vygotsky's (1978) conceptualisation of the Zone of Proximal Development which had informed previous developments in blended learning (Hutchings, Quinney and Galvin, 2014; Hutchings and Quiney 2015). Vygotsky's ideas support socially constructed learning, especially when mediated by technology. We were influenced by Cook (2010) who proposed an extension of Vygotsky's concepts to explain how learners collaborate, using tools to mediate learning (mobile phones, augmented reality, language). This approach underpinned the technology-mediated problem solving where learners (in this case staff) participated in new contexts for learning.

The Assessment and Feedback Toolkit provided a further support mechanism which articulated 'the why' by setting out theories and principles, particularly on assessment design (including: Nicol and Mcfarlane-Dick, 2006; Hounsell, Xu and Tai, 2007; Boud et al., 2010; Bearman et al., 2016) and not simply 'how to' move assessment online. The Toolkit was developed in-house, and available to the wider academic community as an open access resource (Quinney, Holley and Luce, 2019). It contained continually updated materials on well-established topics pertinent to the pandemic - for example, on moving exams online - with weekly blog content spotlighting sections of content. This promoted resources that were both relevant and sustainable, regardless of the adjustments required in response to the pandemic. The change in practice enabled in this way has led to longer term creative and authentic assessment strategies, rather than just being a temporary adjustment.

Encouraging staff to make creative and authentic adjustments to assessment and feedback was operationalised through a combination of live and recorded webinars, tailored to specific discipline context where requested, and expert masterclasses facilitated by our in-house expert (Quinney) with an international visiting professor (Hounsell).

The Faculty Learning Technologist highlighted the importance of rapid adaptations to institutional change for management practices and confidence building: 'The usual change barriers were removed and left us no choice but to adapt, we will be able to offer our students a wider variety and 'blend' as we move more confidently between different learning spaces in the future'. 


\section{Recommendations}

a. Work in partnership: partnering with university-wide initiatives led by the Centre for Fusion Learning, Innovation and Excellence provided a broader range of expertise and formats for support and development, including informal Masterclasses run by leading academics and input from the wider Learning Technology team. These sessions enabled staff to learn with and from people from a wide range of academic programmes. This combination of discipline-specific and broader inter-disciplinary content created a richer learning environment and provided ongoing connections beyond programme teams and departments.

b. Look beyond the short-term: the combination of strategies informed by longstanding teaching and learning theories and new knowledge provided a sustainable set of resoures to change teaching and learning practices beyond the necessary pandemic adjustments.

c. Personalised approach: a focus on individual staff needs as well as institution needs though a supportive humanised approach enabled staff to share concerns and develop confidence. This approach drew upon the community of practice approach advocated by Wenger.

d. Share the learning: further dissemination was achieved through a range of platforms, including individual and institution blogs and social media such as Twitter, enabling ideas to be shared, adapted and adopted more widely, whilst learning from peers in different HEls, including as part of an assessment design sprint with JISC about innovation in assessment at a time of change (Holley 2020a) and a WonkHE blog (Holley 2020b). This local initiative thus gained momentum and informed learning beyond the department, faculty, and institution.

e. Repeat and reinforce. The success of these two examples will be reinforced by continuing to provide opportunities for staff to talk through concerns or challenges, develop further confidence, and increase expertise as we move to a blended/hybrid learning scenario.

\section{References}


Bearman, M., Dawson, P., Boud, D. J., Bennett, S., Hall, M. and Molloy, E. K. (2016) 'Support for assessment practice: developing the assessment design decisions framework', Teaching in Higher Education, 21(5), pp.545-556.

Biggs, J. (2003) Teaching for quality learning at university. Milton Keynes: SHRE and Open University Press.

Boud, D. and associates (2010) Assessment 2020: Seven propositions for assessment reform in higher education. www.assessmentfutures.com (Accessed: 9 August 2021).

Cook, J. (2010) 'Mobile phones as mediating tools within augmented contexts for development', International Journal of Mobile and Blended Learning, 2(3), pp.1-12. https://doi.org/10.4018/jmbl.2010070101.

Conole, G. and Wills, S., (2013) 'Representing learning designs - making design explicit and shareable', Educational Media International, 50(1), pp.24-38. https://doi.org/10.1080/09523987.2013.777184.

Crookes, P. A., Else, F. and Lewis, P. (2020) Signature pedagogies: an integrative review of an emerging concept in nursing education. Faculty of Science, Medicine and Health - Papers: Part B. Available at: https://ro.uow.edu.au/smhpapers1/1085 (Accessed: 9 August 2021).

Holley, D (2020a). JISC policy panel: The assessment (re) design sprint. JISC, 9 April 2020.

Holley, D (2020b) 'Remote Learning means we need to radically rethink assessment', 19 March 2020. Available at: https://wonkhe.com/blogs/remote-learning-means-weneed-to-radically-rethink-assessment/ (Accessed: 9 August 2021).

Horsfall, J., Cleary, M. and Hunt, G. E. (2012) 'Developing a pedagogy for nursing education-teaching', Nurse Education Today, 32(8), pp.930-933. https://doi.org/10.1016/j.nedt.2011.10.022. 
Hounsell, D., Xu, R. and Tai, C. M. (2007) Blending Assignments and Assessments for High-Quality Learning (Scottish Enhancement Themes: Guides to Integrative Assessment, no.3). Gloucester: Quality Assurance Agency for Higher Education. Available at: https://www.enhancementthemes.ac.uk/docs/ethemes/integrativeassessment/guide-no-3---blending-assignments-and-assessments-for-high-qualitylearning.pdf?sfvrsn=712cf981 6 (Accessed: 12 August 2021).

Hutchings, M. and Quinney, A. (2015) 'The flipped classroom, disruptive pedagogies, enabling technologies and wicked problems: responding to the "bomb in the basement"', Electronic Journal of Elearning, 13(2), pp.106-119.

Hutchings, M., Quinney, A., and Galvin, K. (2014) 'Negotiating the triple helix: harnessing technology for transformation', in Yáñez, T. A, Rodriguez, O. S. and Griffiths, P. (eds) Proceedings of the 9th International Conference on E-learning. Valparaiso, Chile, 26-27 June. Valparaiso: Academic Conferences and Publishing International Limited, p.76.

Laurillard, D. (2002) Rethinking university teaching: a conversational framework for the effective use of learning technologies. London: Routledge.

Nicol, D. and Macfarlane-Dick, D. (2006) 'Formative assessment and self-regulated learning: a model and seven principles of good feedback practice', Studies in Higher Education, 31(2), pp.199-218. https://doi.org/10.1080/03075070600572090.

Nordmann, E., Horlin, C., Hutchison, J., Murray, J. A., Robson, L., Seery, M. K. and MacKay, J. R. D. (2020) '10 simple rules for supporting a temporary online pivot in higher education', PsyArXiv Preprints. Available at: https://psyarxiv.com/qdh25/ (Accessed: 9 August 2021).

Quinney, A., Holley, D. and Luce, A. (2019) 'From assessment of learning to assessment for learning: leading assessment policy change supported by and Assessment \& feedback toolkit', ALDinHE Learning Development Conference. Exeter University, Exeter 15-17 April. 
Quinney, A., Lamont, C., Holley, D. and Biggins, D. (2017) 'Embedding the value of learning by extending professional boundaries', Journal of Learning Development in Higher Education, Issue 12, November, pp.1-14.

https://doi.org/10.47408/jldhe.v0i12.417.

Shulman, L. S., (2005) 'Signature pedagogies in the professions', Daedalus, 134(3), p.52.

Todres, L., Galvin, K. T. and Holloway, I. (2009) 'The humanization of healthcare: a value framework for qualitative research', International Journal of Qualitative Studies on Health and Well-being, 4(2), pp.68-77. https://doi.org/10.1080/17482620802646204.

Vygotsky, L. S. (1978) Mind in Society: the development of higher psychological processes. Cambridge MA: Harvard University Press.

Wenger, E. (1999) Communities of practice: learning, meaning, and identity. Cambridge: Cambridge University Press.

\section{Author details}

Anne Quinney is the Academic Lead for Assessment and Feedback in the Centre for Fusion Learning, Innovation and Excellence at Bournemouth University. She has particular interests in curriculum design, blended learning, and assessment and feedback policy, and writes and presents extensively on these subjects. Anne shares her expertise by teaching on the PGCert in Academic Practice.

Debbie Holley is the Professor of Learning Innovation in the Department of Nursing Sciences at Bournemouth University. Her expertise lies with blending learning to motivate and engage students with their learning inside /outside the formal classroom, at a time and place of their own choosing. Within health, she offers evidence-based practice in the development and evaluation of simulation and digital health applications. 
John Moran is the Faculty Learning Technologist for the Faculty of Health and Social Sciences (FHSS) at Bournemouth University. Based in the Centre for Fusion Learning, Innovation and Excellence, he leads on innovation in health, and is an expert in health simulation, 360 filming, and Virtual Realities. 